\title{
Greeks, Barbarians and Alexander the Great: The Formula for an Empire
}

\author{
By Irina Frasin*
}

Under the leadership of Alexander the Great the Greeks reached far into Asia. This extraordinary enterprise was made possible not only by his wellequipped and trained army but also by his revolutionary way of thinking. What facilitated the creation of such a vast empire, apart from his military genius, was his attitude towards the Others, his incredible openness and curiosity towards the difference and the different. This made his relatively short reign have colossal influence in both eastern and western worlds. My paper analyses this moment of meeting between cultures, focusing on the construction of the image of the Other, the different, the barbarian, the enemy and the impact of this ideology upon shaping the empire that Alexander the Great built.

\section{Introduction}

Under the leadership of Alexander the Great, the Macedonians and their Greek allies from the League of Corinth, conquered the East. This extraordinary adventure, that took them far into the heart of Asia and close to the allegedly believed end of the Earth, was made possible by both the strategic and military genius of Alexander (together with the well-equipped and trained army he inherited from his father, King Phillip II) and the Greek thought and philosophy. The Greeks were firm believers in their superiority over barbarians ${ }^{1}$. They imagined that their freedom, their reason and their sense of measure could and should transform them into the leaders of the barbarians, who, in the eyes of Aristotle, were "slaves by nature" 2 . Thus the conquest of the East was pictured as a mission to civilize the barbarians, to bring light and law into the dark and irrational world ${ }^{3}$.

It is quite engaging to understand how the empire could be born in the midst of democracy and how the mission to civilize the barbarians could change the ways of seeing, meeting and understanding the Other, the different, the enemy, the barbarian. Furthermore, the ways and manners used by the ancient Greeks to define and understand themselves and the others were later

\footnotetext{
*Senior Researcher, "Gh. Zane" Institute of Social and Economic Research, Romanian Academy.

1. As seen by Plato, in Laws, III, 693c - 698a or Republic, Aristotle, in Politics, 1253b, 2535; 1255b 10-12 or Aeschylus in The Persians;to name but a few of the most famous examples (all references to Plato, Aristotle and Aeschylus are from the Romanian version of their work as found in the bibliography).

2. Aristotle, Politics, 1252b 5-10.

3. This may be a reflection of Plato's ideas from Republic or Aristotle's from Politics. See also Claude Mosse, Alexandre. Le destine d'un mythe (Paris: Editions Payot \& Rivages, 2001), 126-167.
} 
embraced by the Western culture and political thinking throughout the centuries to justify their supremacy and dominance over the Others.

Alexander's adventure in Asia was an extraordinary opportunity for meeting and knowing the Other, the barbarian. Step by step, one day at a time the great king discovered that the world was much wider and richer than it was originally thought in Athens and that the barbarians were not so uncivilized and unreasonable as Aristotle believed. The legendary king astonished his contemporaries and fascinated generations to come. Alexander the Great was the one who took Greek culture deep into Asia, opening new ways for trade and communications of all sorts. Moreover, even if the idea of political unity that he dreamed about was crushed along with his death, the real legacy he left us proved far more durable. Even if he started the war against the Persians to avenge the Greeks for the losses and humiliations suffered in the Persian Wars ${ }^{4}$, the Macedonian king was not content with simply becoming the master of the Persian Empire. He always wanted to go further, to continue, to conquer more, to know deeper - and this seems to be the origin of the legend that brought him to the end of the Earth and beyond. Far from the image of the burning palace of Persepolis, the mass weddings at Susa seem to announce the dawn of a totally different future; a universal monarchy bringing under a common scepter Greeks, Macedonians and barbarians, all respecting one another. Thus, the young conqueror ignored Greek vanity and showed excellent political sense. Viewed as a tyrant by some, for his new way of thinking and acting, Alexander wanted to build an empire where all different people of different languages, traditions, religious beliefs and heritages could stand and work together in mutual respect for the common good. He did not want to repeat, in the name of Greek imperialism, what Xerxes failed to do in the name of Persian imperialism. It was time for a new way of thinking.

The profound meaning of Alexander's great and daring adventure is remarkably well expressed in his own legend. The king, passionate about adventure, hungry for new discoveries and knowledge and curious for meeting and understanding the Other, is the hero who meets and fights the Absolute Other: the foreigner, the barbarian, the monster. And all his actions show us that this one can be recognized, respected and even loved. We are fully aware that there are many ways of understanding the "first European Great King of the Persian Empire" ${ }^{15}$ and his amazing achievements. Nevertheless, the ancient literary sources and the relics are merely the foundation of the image we have created about Alexander. For our purpose the image constructed around the conqueror throughout the ages is as relevant as the historical truth ${ }^{6}$. As his spectacular campaigns changed the political map of the world, his image and

4. This was his claim as the leader of the Greek Alliance.

5. David Grant, In the Search of the Lost Testament of Alexander the Great (Leicester, Matador, Troubador Publishing Ltd. 2017), 47.

6. The main issue is that no one can prove what determined Alexander to act in the way he did or to understand how he felt. First, the main literary sources available to us are dated from the Roman period, thus they may not be completely accurate. But even if we had literary evidence from Alexander's time, from his official historians, we still could not be sure of their objectiveness. As history is always written by the victors it remains inherently biased. 
goals kept being reflected by many traditions, making of the historical Alexander "the most elusive of figures" 7 .

\section{The Other as Enemy, as Opponent: Greeks and Barbarians}

The meeting, the communication, the discovery of the Other as well as the conflict, war and domination of the Different are problems as long as time. Since the beginning of mankind and continuing with the establishment of stable communities and the emergence of the first cities, there were attempts to meet, to face, to understand and to confront those who were different - belonging to a different tribe, to a different city, speaking perhaps a strange and different language, worshiping different gods and so on. We can find in history examples both for the attempts to confront and conquer the others as well as for communication and tolerance.

Communities in general, and even individuals perceive and define their identity partly by differentiating themselves from what they are not, from an external world that is regarded as alien, different - even if it can be either menacing and dangerous or friendly and admirable. The core idea is that in order to reconsider what we represent we have to detach ourselves from the rest of the world; we have to distinguish between us and the others. Thus the only thing that the others, the rest of the world have in common is the thing that they are different from us; there is no other common trait to make the outside world seem homogenous than the fact that is different from what we are. Considering this we can easily understand how the Other, most of the times, is conceived and described as an antithesis of us; the other looking more like an inverted mirror image than an entity from the real world. Briefly, we need the Other in order to define and determine who we are. We would not question who we are and what we represent if we did not try to see ourselves from the standpoint of the Other.

The other and his/her different group or community is, as we can easily observe, closer or further from us culturally, morally, linguistically or historically. As we have seen before, in extreme cases we are dealing with a total strangeness, with a radical difference. The ancient Egyptians viewed the others so different from them that they even hesitated, in exceptional cases, to see them as humans. They considered their kingdom as the only oasis of peace and order surrounded by an external world dominated by chaos ${ }^{8}$. But there are also groups who have come to admire and befriend the alien and different wide world.

For the ancient Greeks, due to their extended contact with other foreign populations in the time of colonization, we discover very complex ways and manners of understanding the outside world and relating to the others. On one hand they regarded those whose language they did not understand as "barbarians" and, on rare occasions, they doubted if they were rational beings

7. A. B. Bosworth and E. J. Baynham, eds., Alexander the Great in Fact and Fiction (Oxford University Press, 2002), 22.

8. For details see Lewis Spence, Egypt (London: Senate, 1996). 
or mere objects endowed with soul ${ }^{9}$. On the other hand we have also examples ${ }^{10}$ of foreigners regarded with admiration and respect. Thus the Greeks created for European culture and thinking models for analyzing and understanding the foreign cultures both objective and open-minded, but also some generalities, common places whose use overshadow the spirit of inquiry and discovery.

From the beginning of their history, the Greeks were involved in multiple cultural and commercial relations with their non-Greek neighbors. These contacts left their mark on the cultural changes and developments. But a special importance for both the way of understanding the others as well as their common Greek identity happens during the time of the great colonization. It is the era when hundreds of poleis were born, and Greeks from different origin cities came to live together in the new colonies. Thus the spirit of a new discovered community was born and a new solidarity was encouraged possibly by the conflicts with indigenous populations from Sicily and the Black Sea to Asia Minor and further. There is a feeling of belonging, of kinship - as we understand from Herodotus ${ }^{11}$ - regarding common origin, gods, language and traditions. In this time, due to traveling, commerce and cultural exchange the knowledge about the others increases, but it is nonetheless additionally accompanied by elements of fiction - as the edges of the world are inhabited by miraculous and fantastic beings.

The Persian Wars, when the Greeks confronted and defeated the greatest empire of the time, was a decisive moment for changing and shaping the image of the Other; the barbarian, who was merely the one who did not speak Greek, or spoke it with an accent, became the enemy, the opponent, the representative of an irrationally large empire. The image of the others, the foreigners changed both due to the increase of empirical knowledge about new populations but also due to a new discovered feeling of superiority that animated the Greeks after the defeat of Great Kings, Darius I and Xerxes. If the fragile alliance between tiny poleis could defeat the colossal structure that united countless strange populations it must certainly mean that the Greek poleis possessed something that set them apart from the rest and made them stand out, made them unique, special and unbreakable.

The Persian Wars have been analyzed countless times by different authors, from different perspectives, but what stands out almost every time is the contrast between the freedom of the Greeks and the tyranny of the barbarians. The hybris of Xerxes, who wanted to build a bridge over the Hellespont, is regarded as an irrational attempt to surpass this essential difference and extinguish it by bringing the Greeks in his overwhelmingly large empire. The rule of law, the responsibility of the leaders, the liberty and political equality between the Greek citizens were on that occasion contrasted with the tyranny of the Persian rule, the representation of the power and willing of one single man. The lack of liberty of the Persians was used to explain the defeat of the great

9. Aristotle, Politics, II, 152b.

10.The most famous of them is the 'Atlantis' of Plato.

11. Herodotus, Histories (Wordsworth Editions, 1996), 669. 
empire - as the Persian soldiers were led into battle under the whip ${ }^{12}-$ and the famous, celebrated and amazing victory of the Greeks.

The luxury, weakness, promiscuity, savagery, lack of courage, cruelty and the incapacity to organize themselves become attributes of barbarians. And gradually the differences between Persians, Thracians, Egyptians, Scythians, Indians and other foreign nations become blurred as they were seen all as barbarians, first and foremost - a general population with general and common traits ${ }^{13}$. It is very important to keep in mind one thing: most certainly the Greeks did not forget or ignore what they admired and learned from the others across the centuries. However, what they cannot accept, or ignore is the lack of freedom. The most criticized attribute of the barbarians is their lack of liberty, their servitude, their obedience, their "natural slavery". This can be easily traced if we focus on the ideal political model - the democracy invented by the Greeks. This society supposes the existence of free and equal citizens who obey willingly to the law that they themselves created. This becomes the model for all that is civilized and rational in contrast with the barbarian society that embodies different stages of irrationality. The freemen obey only the law whereas the barbarians are the slaves of an absolute monarch. This becomes the fundamental distinction between the law - that is Greek - and the slavery - that is barbarian. The courage and the respect of the law become qualities of all beings endowed with reason and it is opposed to the lack of measure and selfcontrol that lead to weakness and cruelty. Therefore, regarding these irreconcilable differences, there can only be enmity and opposition between the Greeks and the barbarians.

By contrast the war between the Greeks (as we discover in the Peloponnesian War) was played by different rules. Unlike the radical opposition between the Greeks and barbarians, between Greeks of different poleis there was no natural enmity; the "natural enemy" of the Greeks was the Barbarian, between each other the war must be played in moderation ${ }^{14}$.

The differences between Greeks and barbarians and the discovery of the Other, have a long and complex history but, by simplifying we can reduce it to a question of values. It is obvious that the speeches of generals and politicians of the time abound in praise to the Greek virtue. It is perfectly understandable if we take into account that those speeches were made to motivate, to inspire, but what is really impressive is their attachment to these values. The Greeks loved the virtue, wished that it was something that every citizen could achieve and criticized its absence - in themselves or in others. Thus, if we follow how the Greeks viewed the barbarians we can also understand how they pictured their own virtues, what they valued and what they despised. The most common distinction between Greek and barbarian is the dependence of the latter on impulse and desire; these made it impossible for barbarians to understand and value balance and measure (marks of men guided by reason), the true

12. Herodotus, Histories, (Wordsworth Editions, 1996), VII, 34-35, p.527.

13. For details see Thomas Harrison ed., Greeks and barbarians (Edinburgh University Press, 2002), 193-210.

14. For details see Michel Debidour, Les Grecs et la Guerre. Ve - Ive siecles (Editions de Rocher, 2002), 67, 113-115. 
guidelines on the road to freedom. Aeschylus in The Persians makes a messenger say the following words to queen Atossa, the daughter of Cyrus the Great referring to the Athenians "they are the slaves of nobody, they are not the servants of any man"15.

Even if it may be tempting, we must avoid understanding this opposition Greek - barbarian as ethnocentrism. Most of the texts refer not to innate traits, but to obtained virtues. We can become barbarian living among the barbarians, but we can also learn the Greek way of life. Most of the time ${ }^{16}$, we are not dealing with a difference of nature, but a difference of culture - the Greek culture is superior, but is also open to everybody. Isocrates is the most famous messenger of these ideas "our city, in what concerns philosophy and rhetoric, is much above the other cities, thus making its disciples become the teachers of others and Athens has made the name Greek to be more a symbol of civilization than represent a people. Therefore the name Greek should refer to those who had the privilege of sharing the Greek culture, more than to those who are Greek by birth" ${ }^{17}$.

We are reading a beautiful declaration about universal values, when the laws of the Greeks become the laws of all others. This kind of declaration may sound very concerning for us today - regarding that now, after all the traumatic experiences recorded by history, we see that all the people, ethnic groups, big or small, similar or strangely diverse carry their own values and have the right of respect.

\section{City-States, Alliances, Empire}

The ancient Greeks were living in city-states - the political regime of these states varied between democracy, aristocracy and even tyranny. The polis was based on the cohesion and common interest of its citizens.

In its Golden Age, Athens, the model for the Greek democracy, had become a great cultural center for the entire Hellenic world that it began to dominate both by its power and wealth. It is very interesting to observe and understand how this cradle of freedom, democracy and equality between citizens led to the emergence of a very original political system, different from both the neighboring kingdoms and the oriental empires. The explanation for this phenomenon seems to reside primarily in the mentalities about the role of the individual in the affairs of the city-state and the special dignity of the citizen. This makes the empire of Alexander the Great, the Hellenistic states that followed and even the Roman Empire, in spite of all oriental influences that they got, never resemble the eastern empires too much.

15. Aeschylus, The Persians, v242.

16. Aristotle and his theory about the slaves by nature was an isolated example.

17. Isocrates in Pagini alese din oratori greci (Bucuresti: Editura pentru literature, 1969), 138. 
At the pinnacle of its glory, Athens was both a model for democracy, liberty and philosophy, but also a strong and feared city-state for its allies ${ }^{18}$. When we look at the Athenian democracy today we are fascinated by its extraordinary achievements, but also amazed by its less glorious sides. The democratic ideal, as conceived by the ancient Greeks supposed a society formed by free and equal individuals - citizens who obey only the laws that they make for themselves. In this way they get to govern an independent and autonomous state. This ideal combined with the feeling and ideas of superiority achieved after the victories of the Persian Wars led to the beautiful declaration of Isocrates - that the Greek' laws, rules and way of life could become the way of life for everybody else.

To understand those changes that led to that astonishing transformation from polis and democracy to symachia and empire - we should start by observing the main characteristics of the city-state. Each polis, regardless of its size, had to be free, independent and autonomous, having its own political and religious institutions, sometimes even its special coinage. As we have understood from Herodotus, all the city-states had a clear consciousness of belonging to a larger Hellenic community, sharing common ancestors, gods and rituals, traditions and rules, and, naturally, the Greek language. This is why the alliance with the barbarian against other fellow Greeks was regarded as the highest act of treason. The polis could not admit any form of subordination to another state. This made the union of the Greek city-states in federations and alliances to be always short-lived and often problematic.

The power of the city-state over its citizens (and, of course, over all its other inhabitants) was absolute; its authority being the source of all the rights and obligations for the people, but also reaching all other activities and aspects of life ${ }^{19}$. Inside the polis we shouldn't confuse freedom for anarchy and it is somehow obvious that only by obeying the laws could all the citizens be free. This is the very basic place where the special dignity of freemen resides: their community was the source of the laws and the respect of these was the source of liberty.

In democracy "being a citizen was a duty, regarding the cultivation of virtue; it was a duty excluding any other work beside"20. In democracy the power was gained and maintained by the skilled usage of the public discourses $^{21}$. The fate of the community was decided in the Assembly; the one who controlled or seduced the people was guaranteed to have his will and ideas triumph. This permanent confrontation, this permanent struggle for public recognition, for success, for surpassing all opponents can be understood as a permanent effort for glory. Thus the values of the aristocratic society of fair

18. Allies transform gradually into subjects because they cannot abandon the alliance as they please and as the tribute they pay is used by Athens not only for reinforcing the fleet but also for embellishing its temples.

19. In this context it is very interesting to analyze the meaning that the ancient Greeks gave to freedom itself, but this is not the subject of the current investigation.

20. Pierre Vidal-Naquet, Vanatorul negru. Forme de gandire si forme de societate in lumea greaca (Bucuresti: Eminescu,1985), 389.

21. See Plato's dialogue Gorgias and also Marcel Detienne, Stapanitorii de adevar in Grecia arhaica (Bucuresti: Meridiane, 1996). 
competition and constant effort for glory seem to be maintained; the main difference being that the rivalry in democracy was supposed to be among free and equal men / citizens.

It is quite obvious that all these rights and liberties concerning such a large number of people were not easy to maintain. Considering the fact that plentiful of poor citizens were struggling to survive it is not difficult to imagine that, even if the resources available were shared reasonably and equitably (things possible only in utopia) the resources available in just one city-state would have ended by not being enough for all the population. So inevitably in one point in time the city-state had to rely on resources from abroad - that it could get by plunder and war, or by forging an empire that would receive its tribute from its subjects. We shall look at both possibilities: first the forming of an alliance that nobody could escape from, ruled by a powerful polis - the case of the Delian League, and second by war and conquest, replacing the city-state with larger territorial units - the case of the empire of Alexander the Great, and later the Hellenistic states and the Roman Empire.

The time between the Persian Wars and the Peloponnesian War is highly important for understanding this transition from city-state and democracy to empire. We know this period mainly due to Thucydides. The Delian League, the famous alliance formed to protect the Greek poleis from outside menace, was gradually transformed into an Athenian maritime empire. Increasing its power and influence after the victory of Salamis, Athens ended up consolidating its privileged position by founding the League of Delos - an alliance $^{22}$ constituted theoretically for mutual protection and support. The center of the alliance was - formally at least - the sanctuary of Delos, the place where the treasury was kept and the meetings of the allies took place. Athens had the hegemony, it had the military command, but all the other members were autonomous ${ }^{23}$. Although the council of the allies had the power of decision and this was by vote, and Athens had but one vote, nobody could in fact measure up with the famous city.

The disproportion between the power of Athens and the other city-states continued to grow until the League, initially an association between partners, was turned into an empire dominated by a super-power. Thus the symachy - a free consented alliance, was turned into an arche - an imposed domination. Founded to protect the Greek against a Persian attack, the League fulfilled its mission; but it also allowed Athens to increase the life quality of its citizens, fortify its famous fleet ${ }^{24}$, build and embellish its famous temples.

To be able to be a democracy at home, Athens had to become an empire outside. The existence of this empire, that the Athenians themselves viewed as a tyranny was growing due to the mirage of power, prestige, prosperity and

22. A symachia was a military alliance created for mutual defense in front of a common threat, a common enemy - in this case the Persian Empire. See Thomas Harrison, (ed.), Greeks and barbarians (Edinburgh University Press, 2002), 244.

23. Only in theory, as in fact they could not go out from the alliance in case they chose to.

24.The fleet was formed from the poor citizens, who after their success - as the fleet was both the pride of Athens and the guarantee of its power - started to ask for more than just survival; thus, needing more money Athens started to think about domination outside the Greek world - see the expedition in Egypt in 459 B.C. 
security which were all so hard to resist. The concern for democracy and its values and the efforts to try and understand how these values were co-existing with the imperialistic rule were a constant preoccupation for the rulers and their opponents. Pericles, the great symbol of Athenian democracy was telling his citizens "Your empire is now a tyranny: maybe it was a mistake to have formed it, but certainly now it is dangerous to give it up" 25 .

\section{The Empire of Alexander the Great: The Other as Ally, as Co-citizen, as Friend}

The reign of Alexander the Great had an incredible and long lasting effect on both conquerors and conquered, on both western and eastern worlds that he tried to bring together in his short-lived empire.

Alexander was, most probably, the greatest military leader the world has ever known; and in his brief reign he changed the known world. He became king of Macedonia when he was twenty and when he was thirty he had already reached the edges of the known world, had defeated the most powerful empire of his time and had been regarded as a living god. The tremendous success that he enjoyed in his short life overshadowed countless generations of glorious generals from Caesar to Charlemagne, from Napoleon to Eisenhower. Both admired and despised, Alexander has always been a character to inspire high passion and debate. This made numerous historians along the centuries view in Alexander a man of their own ideals; and this is why the deeds and personality of the Macedonian king never cease to fascinate us, as he seems to come out of time and by his example still serves as model for us today.

Everything about Alexander is fascinating; thousands of books and articles have been dedicated to solving the mysteries of his life ${ }^{26}$. For some historians, Alexander was the creator of a global empire, the author of the ideal of a united world, paving the way for the religions of love and peace. For others, he was the one who murdered thousands of people - apart from the battle field seeming incapable of quenching this thirst for blood. He was the one who embodied the most noble of virtues, but also the most terrible of vices; he was wise and temperate, but also abusive and tyrannical; a sensitive and devoted young man, but also a man capable of murdering his closest friend in fits of insecurity. His numerous portraits are both contradictory and controversial.

But this mystery surrounding his life has not been invented by modern historians; it has been passed along the generations going back to the main historical sources we have on Alexander. His amazing and incredible career both fascinated and puzzled his contemporaries, who seem not to have known how to understand him; and the generations to come inherited this ambiguity.

25. Thucydides, The History of the Peloponesian War (London: Wordsworth Editions, 1997), II, 63.

26. For further details on Alexander's life and campaigns see Carol G. Thomas, Alexander the Great in his World (Blackwell Publishing 2007), Ian Worthington (ed.), Alexander the Great. A reader (Routhlege, 2007), or A.B. Bothworth and E.J. Baynham (eds.), Alexander the Great in fact and Fiction (Oxford University Press, 1999). 
He was the model leader for both his generals and generations of generals to come. He literally led from the front, and his quest of glory blended gracefully with his brilliant tactics and strategies. He encouraged everybody, he motivated his men like no other, he raised them to excellence and made them the best versions of themselves. And for that he had their love and devotion. We know that he never lost a battle and he treated his defeated enemies with magnanimity that dazzled his contemporaries ${ }^{27}$. But also he never forgave betrayal or stubborn opposition and those enemies were treated with cruelty hard to imagine $^{28}$.

His brilliance as a general ${ }^{29}$ is seen both in his magnificent battle plans but also in his extraordinary ability to adapt to new and puzzling situations. His strength was his capacity to realistically evaluate new, unexpected circumstances and to decide both quickly and correctly the best way to go. $\mathrm{He}$ had the qualities of a great general, perhaps the greatest in history, but also those of a great leader of men.

Alexander was the one to break the barriers of the city-state and to bring the Greek culture and philosophy deep into the heart of Asia, thus opening trade routes and political ties even if the unity of his empire proved less durable. The Greeks - bothered by overpopulation and poverty, as we have seen before - found a solution for their problems, as the massive colonization created fruitful combination capable of both absorbing a large quantity of population and also supplying resources to the mainland.

The deeds and decisions of Alexander of Macedonia are the kind to fascinate, disturb and baffle - as he was not satisfied to become the conqueror of the Great King - the traditional enemy of the Greeks - and the richest man alive in that time, but he wanted to continue the march till the edges of the world, till he reached the Outside Ocean. He wanted to bring all the world under his rule. But his need to conquer more and go further didn't come out of greed or hunger for riches and power; it came from a great curiosity - a special ability to keep being amazed and mesmerized by the world around. His pothos for more conquest, for going ever further was fueled by his never quenched thirst to explore. It is not difficult to imagine that the only possible connection of such a vast territory populated by such different people could be only the

27. As in the case of the family of Darius III, after the battle of Issos (Arrianus II, 12, 7 , Diodorus XVII, 37, 5-6, Curtius Rufus III, 12, Plutarch, 21) or the treatment of the Indian king Poros after his defeat (Plutarch, 60). All references to Alexander's ancient sources Arrianus, Diodorus, Curtius Rufus and Plutarch are from the Romanian version of their works as found in the bibliography.

28. As the case of Batis of Gaza, whom Alexander dragged behind his chariot around the city - killing him in this way (Rufus IV, 6); also the case of Bessos the murderer of Darius III (Curtius Rufus VII, Arrianus IV, 7,3).

29. For further details see Lance Kurke, The Wisdom of Alexander the Great (New York: Ibooks, 2004) and David J. Lonsdale, Alexander the Great. Lessons in Strategy (Routledge, 2009), Frank L. Holt, Into the Land of Bones, Alexander the Great in Afghanistan (University of California Press, 2006); and also for Alexander's generalship see J.F.C. Fuller, The Generaship of Alexander the Great (Wordsworth Military Library, 1998), Donald W. Engels, Alexander the Great and the Logistics of the Macedonian Army (University of California Press, 1997) and Stephen English, The Field Campaigns of Alexander the Great (Pen \& Sward Military, 2011) and The Sieges of Alexander the Great (Pen\&Sward Military, 2009). 
authority of the sovereign. Alexander clearly understood this ${ }^{30}$ and the premature collapse of his empire does not show us that such a construction was not viable, but that it needed an Alexander to keep it going.

The most spectacular thing about the young king and his great empire is that, even becoming the master of all these different populations, he disregarded the Greek pride ${ }^{31}$, proving to be a very skillful politician. Herodotus told us in his Histories about the permanent conflict between Greeks and barbarians - as we have seen between civilization, liberty, democracy and savagery, slavery, tyranny. This conflict was transformed into a fight between two different types of existence, two different kinds of humanity, two different models; it became more than the conflict between two peoples. The Macedonian king disregarded this way of understanding and brought under his rule Greeks, Macedonians, Persians, Egyptians, Scythians, Bactrians, Indians and others, all subjects under the same sovereign, living peacefully together ${ }^{32}$ like in the time of the great banquet of Opis. Instead of treating the others as inferior barbarians, Alexander was curious and open. He considered the barbarians worthy of sharing his table and the riches he acquired and possessed. He tried to know the others, their way of life, their religious beliefs, to understand them. And even if he did this only for the sake of understanding better his opponents, this already brings him in a special category of leader of men.

The conquest and empire of Alexander the Great represent a turning point concerning the relations between victors and vanquished. He tried to promote the idea of a peaceful, united world, where understanding and mutual communication and respect should rule. Thus the famous distinction Greek barbarian started to fade ${ }^{33}$. Alexander's contemporaries, and the historians and philosophers of the centuries to come, wrote about the deep meaning of Alexander's exploits. Plutarch, due to his role as a conqueror and peacemaker, considered him a philosopher and compared him to Plato. Even if his attempts to bring together victors and vanquished brought him hatred and misunderstanding from his generals and contemporaries, it also brought him the admiration of the future centuries. He seems to have understood the value of opening up to other cultures, the need of tolerance and modesty and the fact that the acceptance of the Others is accompanied by challenges of our own preconceptions.

30. As he ruled in a different way, different populations: he was simultaneously Macedonian king, hegemon of the League of Corinth, pharaoh and son of Amon, Great King of all Asia. This may have been indeed dictated by practical reasons, as it would have been simply impossible to dominate such a huge territory only with soldiers brought from Macedonia and the allies without the cooperation of the locals. Nevertheless this should not make us neglect the extraordinary vision of Alexander.

31. Theoretically, at least, as the hegemon of the League of Greek allies, he must have been aware of what was expected of him. But "if Alexander was misunderstood, he himself may have failed to grasp the subtelties of those around him when journeying of the road Aristotle would have bade him follow", David Grant, In Search of the Lost Testament of Alexander the Great (Leicester, Matador, Troubador Publishing Ltd., 2017), 66.

32. See Jean Sirinelli, Urmasii lui Alexandru cel Mare (Bucuresti: Teora, 2000), 21.

33. As we can see tracing the evolution of the Greek - barbarian opposition. For details see Thomas Harrison ed., Greeks and Barbarians (Edinburgh University Press, 2002), 257-277. 
Alexander the Great is so much more than the founder of an empire with an uncertain geography; he is the one who practically "extended" the polis to contain the whole world ${ }^{34}$. This way, he saw all the populations that he conquered as citizens of his newly founded empire. To keep such diverse populations united under a common idea and goal he, as a brilliant politician that he was, understood the importance of learning from the Other, of trying to see the world through the eyes of the Others. To keep the empire glued together everybody needs to have a place, all the subjects / citizens must work together for a common good. And achieving this could only be the work of a very firm and strong leader. Thus even if after his death his colossal empire fell apart, this lesson proved far more durable - the idea of a fusion between the two divided halves of the world, East and West brought together by one single rule. This idea lived on - admired by Julius Caesar and his successor Augustus - and thus we can even see the Roman Empire as a fulfillment of Alexander's dream ${ }^{35}$.

The life and deeds of Alexander have been told and retold countless times in both Europe and Asia, getting the spices, details and interpretations specific to the time and space where they were unfolding. Thus the image of the conqueror has been reflected in countless mirrors and embellished and enriched with time till it got the shape of the myth ${ }^{36}$ we know today. But the heart of this idea was the aura that Alexander cast around himself in the time of his life as a model leader, a perfect and fearless warrior, a general that lead his army from the front, a king that understood and cared for his people. His extraordinary authority came from the love and respect that he had from his subjects. He had taken all the responsibility for his position with his courage, intelligence and devotion and for that he had the total loyalty of his people. He had a natural charisma, the authority of an inborn leader. Thus his main concern was to keep his subjects in harmony, to keep them happy and content together, to unite them and avoid any possible tendencies to division. And he did all these by the power of his own example.

Very early, the idea of world domination was associated with Alexander the Great. No matter the previous attempts ${ }^{37}$, this idea shows primarily the Greek intent to emphasize the universal civilizing mission of the conqueror. The image of the cosmocrator became more and more popular in the Hellenistic and Roman times. In this resides the universality and eternity of Alexander's conquests; and this is the way in which any type of despotic ambition and lack of measure is denounced. The tradition made that his personality, or more than that, the idea of "Alexander the Great", be a carrier of special significance and meaning. These ended up by leaving behind the historical figure.

34. In David Grant's terms "Alexander may indeed have been an original kosmopolites, a self-declared citizen of the world" D. Grant, In Search of the Lost Testament of Alexander the Great (Leicester, Matador, Troubador Publishing Ltd., 2017), 9.

35. See Alexandru Suceveanu, Alexandru cel Mare (Bucuresti: Editura Academiei Romane, 1993), 161.

36. For more details about the legend see Claude Mosse, Alexandre. Le destine d'un mythe (Paris: Editions Payot \& Rivages, 2001) and A.B. Bothworth and E.J. Baynham, Alexander the Great in Fact and Fiction (Oxford University Press, 2002).

37. By the Pharaoh or the Great King, for instance. 
Analyzing the history of the Macedonian king and questioning the specificities of his empire in comparison with others, writers and historians brought ever new meaning for the well-known facts. Thus, Alexander's life became more than a succession of events and he himself became a symbol. $\mathrm{He}$ got to represent the sign or symbol of a special kind of presence that brings universal concord and unity.

Even from the beginning, there have been fiery debates among Alexander's historians to understand if the Macedonian king was just a tyrant, favored by luck and fate, who wanted world domination, or a wise ruler who dreamed of universal peace; if he was an ill intended genius of Evil, or a true philosopher and a precursor of modern cosmopolitanism. Then and now the consensus is missing. If we begin by analyzing the facts we can clearly see at least the following: he enrolled in the army Persians, but kept in the key points Macedonians ${ }^{38}$; he organized the mass marriage of Susa and the reconciliation festivities at Opis where "a common government and the establishment of a good understanding" ${ }^{39}$ was celebrated; he respected all the religions and the gods in his empire; he himself venerated foreign gods and even asked his subjects to acknowledge him as the son of Zeus-Amon; he was ruling simultaneously as Macedonian king, hegemon of the League of Corinth, pharaoh and son of a god, and Great King of all Asia; before his untimely death he was preparing an expedition around the Arabian peninsula and probably to Carthage. Summing up and analyzing these facts can we conclude that Alexander was a symbol of the policy of annexations, assimilation, a symbol of imperialism or maybe something different, altogether new?

In time, the image of the heroic and divine king from the classical and medieval legends was replaced by Johan-Gustav Droysen ${ }^{40}$ by that of the founder of a new era; thus making Alexander the symbol of a new beginning, the creator of the western-eastern fusion, the founder of a mixed, hybrid civilization. Alexander became the unifier par excellence and the British historian William Woosthorpe $\operatorname{Tarn}^{41}$ made him the man of universal concord, peace and understanding. After the Second World War, Ernst Badian ${ }^{42}$ considered Alexander a ruthless totalitarian tyrant. Finally, Alexander became a realistic politician, a symbol of political lucidity. From this perspective his policy was not intended to merge different cultures or to Hellenize the barbarians, but to rule effectively an ever larger territory keeping in use the structures and administration that he found. Pierre Briant ${ }^{43}$ considers that the so-called "fraternization" of all the peoples dreamed by Alexander was no more

38. With very rare exceptions - like Oxyarthe; and the Persians in the army were trained following the Macedonian program

39. Arrianus, VII, 11.

40. J.G. Droysen, Histoire de l'Hellenisme (Paris : Errest le Roux, 1883).

41. W.W. Tarn, Alexander the Great (Cambridge University Press, 1951). 425-444.

42. Ernst Badian, "Alexander the Great and the Unity of Mankind," Historia VII (1958),

43. Pierre Briant, Alexander the Great. The Heroic Ideal (New York, 1996a), Histoire de l'empire Perse. De Cyrus a Alexandre (Paris: Fayard, 1996b), Alexandru cel Mare (Bucuresti: Corint, 2001). 
than the merger of two aristocracies. Even if he changed the people, he kept the structures.

Today we can only smile when we read what Droysen was writing when he thought there was no difference between victors and vanquished. Even if Alexander, along his campaigns, had been trying to realize collaboration and closeness in spirit, he realized, upon his return from India, that just a few years had been enough for hatred, misunderstanding, conflict and opposition to prevail. Thus we can clearly notice that even after the mass marriages of Susa, the reorganizing of the army and the reconciliation of Opis the hierarchy continues to persist ${ }^{44}$. But we must also accept that, even if there was not a homogeneous world, where differences disappear, this does not necessarily mean that we cannot recognize a unified world.

Tzvetan Todorov has a very interesting gallery of portraits of travellers. At a first glance we might be tempted to see Alexander the Great fitting in the first type, that of the assimilator: he "is the one who wants to change the others to look more like him; in principle he is a universalist (he believes in the unity of mankind), but he usually interprets the differences with the others in terms of lacking compared to his ideal" ${ }^{15}$. It is true that Alexander was the one who took the Greek culture deep into Asia, but he believed in the possibility of a universal empire. It is obvious that without his burning curiosity to explore the foreign cultures that he encountered and discovered along with the admiration and respect for the different populations that he conquered and brought under his rule, his empire would have probably looked very different. The young Macedonian who conquered the world also wanted (equally maybe) to know it and understand its mysteries ${ }^{46}$. So, as Plutarch had already noticed long ago, what still remains Alexander's particularity is that he chose to act as a true philosopher: "The philosopher is universalist - as was the assimilator, with the special difference that, due to his careful observation of the differences, his universalism is no longer an ethnocentrism" $" 7$.

\section{A Few Closing Lines}

The world of today is offering us a great variety of ideas and perspectives, a vast diversity of cultures and ever closer connections to those different from us. We may sometimes imagine that we have a more united and homogeneous world due to globalization; however, at the same time we cannot fail to notice the constant challenges and unrest this unity and closeness bring. The dream of Alexander the Great of a united world seems today so close to be achieved and yet it seems so far away. Our greatest challenge seems to be the crossing of

44. Macedonians and Greeks continued to hold the key positions, followed by the Persians; the other populations are their subordinates. We know that Alexander accepted in his army members of all different populations, but these always had subordinate places.

45. Tzvetan Todorov, Noi si ceilalti. Despre diversitate (Bucuresti : Humanitas, 1999), 464.

46. And here we can recognize the student of Aristotle. In his desire to know the world and understand its mysteries, Alexander surrounded himself with philosophers, artists, scientists, geographers, doctors and astronomers.

47. Tzvetan Todorov, Noi si ceilalti. Despre diversitate (Bucuresti: Humanitas, 1999), 475. 
cultural divisions, but without neglecting, or denying any cultural identity. As we live closer together, and we are more dependent on each other than in any other period in history, we have to learn the true meaning of respect and responsibility. We have to understand tolerance and the meaning of living together in diversity which can be both a great challenge but also an opportunity for growth, as in growing and becoming together, reaching togetherness - in respect and mutual understanding.

"Either in this century we will learn how to build a common civilization with which each one can identify, united by universal values, led by the firm belief in the human adventure, and enriched by all our individual cultures; or we shall fall together into a common barbarity" ${ }^{\prime 4}$. These words seem to describe perfectly the dream of Alexander the Great and also the extraordinary challenges he faced and affirm the need to get to a common civilization of living together, reach a shared culture for different people of different traditions and backgrounds and diverse believes and languages. If we are to live together (and at this point in history it looks like the choice had been already made for us) we have to learn that we cannot rely on a single magic solution for this. The more we realize we are all different, hard to unify, the more we find each other already united by invisible ties of economy and politics, of culture or geography. We have to build new ways of interaction, of living and becoming together. Even if in our interpretation of the history of Alexander the Great we are influenced by our own history, still we have a great example to follow and to guide us in the stormy times we are experiencing.

The greatest enemy of our time seems to be the fear; the fear of the Other, the enemy, the foreigner, the terrorist, the migrant, the neighbor, and even ourselves. And the only antidote to this, as the myth of Alexander so spectacularly shows us, is love; love of the Other, of the barbarian, the stranger, the different. We protect only what we love and we love only what we know. In order to know and understand the Others we need an emotional connection. We need to surpass the indifference and open wide our curious eyes to the new realities and people that challenge our confortable preconceptions. We need to see the world with ever renewed curiosity and fascination and never stop questioning and exploring

\section{Bibliography}

Aristotel. Politica. Bucuresti: Iri, 2001.

Arrianus, Flavius. Expeditia lui Alexandru in Asia. Bucuresti: Minerva, 1996.

Badian, Ernst. "Alexander the Great and the Unity of Mankind." Historia, VII, (1958), 425-444.

Bothworth, A.B., \& E.J. Baynham, (eds.) Alexander the Great in Fact and Fiction. Oxford University Press, 2002.

Briant, Pierre. Alexander the Great. The Heroic Ideal. New York, 1996a.

48. Amin Maalouf, De dereglement du monde. Quand les civilisations s'epuisent (Le livre de Poche, Grasset, 2009), 32. 
Briant, Pierre. Histoire de l'empire Perse. De Cyrus a Alexandre. Paris: Fayard, 1996b.

Briant, Pierre. Alexandru cel Mare. Bucuresti : Corint, 2001.

Debidour, Michel. Les Grecs et la Guerre. Ve - Ive siecles. Editions de Rocher, 2002.

Demostene. Eschine, Licurg, Isocrate. Pagini alese din oratori greci. Bucuresti: Editura pentru literatura, 1969.

Detienne, Marcel. Stapanitorii de adevar in Grecia arhaica. Bucuresti: Meridiane, 1996.

Diodor din Sicilia, Bibliotaca istorica. Bucuresti: Sport-Turism, 1981.

Droysen, J.G. Histoire de l'Hellenisme. Paris : Errest le Roux, 1883.

Engels, Donald W. Alexander the Great and the Logistics of the Macedonian Army. University of California Press, 1997.

English, Stephen. The Field campaigns of Alexander the Great. England: Pen \& Sward Military, 2011.

English, Stephen. The Sieges of Alexander the Great. England: Pen \& Sward Military, 2009.

Eschil. Tragedii. Bucuresti: Univers, 2002.

Fuller, J.F.C. The Generalship of Alexander the Great. Wordsworth Military Library, 1998.

Grant, David. In Search of the Lost Testament of Alexander the Great. Leicester. Matador, Troubador Publishing Ltd., 2017.

Harrison, Thomas (ed.). Greeks and Barbarians. Edinburgh University Press, 2002.

Herodotus. Histories. London: Wordsworth Editions, 1996.

Holt, Frank L. Into the Land of Bones, Alexander the Great in Afghanistan. University of California Press, 2006.

Kurke, Lance. The Wisdom of Alexander the Great. New York: Ibooks, 2004.

Lonsdale, David J. Alexander the Great. Lessons in Strategy. Routledge, 2009.

Maalouf, Amin. De dereglement du monde. Quand nos civilisations s'epuisent. Le livre de Poche. Grasset, 2009.

Mosse, Claude. Alexandre. La destine d'un mythe. Paris: Editions Payot \& Rivages, 2001.

Platon. Opere. Bucuresti: Editura Stiintifica si Enciclopedica, 1986.

Platon. Dialoguri. Bucuresti: Iri, 1996.

Platon. Legile. Bucuresti: Iri, 1995.

Plutarch. Vieti paralele. Bucuresti : Editura stiintifica, 1996.

Quintus Curtius Rufus. Viata si faptele lui Alexandru cel Mare, regale Macedonienilor. Minerva. Bucuresti, 1970.

Sirinelli, Jean. Urmasii lui Alexandru cel Mare. Bucuresti : Teora, 2000.

Spence, Lewis. Egypt. London: Senate, 1996.

Suceveanu, Alexandru. Alexandru cel Mare. Bucuresti: Editura Academiei Romane, 1993.

Tarn, W.W. Alexander the Great. Cambridge University Press, 1951.

Thomas, Carol G. Alexander the Great in his World. Blackwell Publishing. 2007.

Todorov, Tzvetan. Noi si ceilalti. Despre diversitate. Bucuresti: Humanitas, 1999.

Thucydides. The History of the Peloponesian War. London: Wordsworth Editions, 1997.

Vidal-Naquet, Pierre. Vanatorul negru. Forme de gandire si forme de societate in lumea greaca. Bucuresti: Eminescu, 1985.

Worthington, Ian (ed.). Alexander the Great. A Reader. New York: Routhledge, 2007. 